\title{
Variation in Actual Evapotranspiration of Green Chilli Inside and Outside the Rooftop Greenhouse under Deficit Irrigation
}

\author{
A. Chopda, A.P. Sahu, D.M. Das" ${ }^{*}$ B. Panigrahi and S.C. Senapati \\ Department of Soil and Water Conservation Engineering, College of Agricultural \\ Engineering and Technology, OUAT, Bhubaneswar, India \\ *Corresponding author
}

\section{Keywords \\ Actual \\ evapotranspiration, \\ Greenhouse, Green \\ chilli, Deficit \\ irrigation}

Article Info

Accepted:

22 July 2018

Available Online:

10 August 2018

\section{A B S T R A C T}

Progressive increase in urban area, more particularly with construction of buildings is reducing the availability of land for agriculture. The demand for food is also rapidly increasing with increase in population. Hence, it is difficult to feed the growing population with limiting land resources. In that context, there is ample scope for rooftop cultivation to solve the problem of land shortage for agricultural production. Proper irrigation scheduling for crops grown on rooftops is yet to be established. Irrigation scheduling is only possible by knowing the actual crop evapotranspiration. Rooftop greenhouses are being found more suitable and widely adopted for rooftop cultivation due to their advantages of protecting the crop from biotic and abiotic agents. It also enhances the yield and product quality. Irrigation scheduling differs inside and outside the greenhouse due to the variation in climatic condition, which leads to the variation in actual crop evapotranspiration. It also varies with altitude. Hence, keeping this research gap in view an experiment was conducted at rooftop of the College of Agricultural Engineering and Technology, OUAT, Bhubaneswar to determine actual crop evapotranspiration of widely grown vegetable crop green chilli. Both inside and outside crop evapotranspiration and their variations were studied using water balance model under four MAD levels of deficit irrigation. Highest crop evapotranspiration was found to be $312.89 \mathrm{~mm}$ inside the greenhouse which was lower than the crop evapotranspiration outside greenhouse for treatment under 10\% MAD level. The treatment with 10\% MAD level performed best amongst all other treatments in terms of plant growth and crop yield. The maximum yield was $268.5 \mathrm{~g} / \mathrm{plant}$.

\section{Introduction}

Water is an essential and precious resource, which greatly influences our ecosystems and agriculture. India receives an average annual rainfall of $1170 \mathrm{~mm}$. Though India is considered rich in terms of annual rainfall and total water resources, its uneven geographical distribution causes severe regional and temporal shortages. Greenhouse farming also known as protected cultivation, presently is one of the most widely used farming systems to provide and maintain a controlled environment suitable for optimum crop production leading to maximum profits. This includes creating an environment suitable for working efficiency as well as for better crop growth. The main advantage with the 
greenhouse farming is round the year production, which is not possible in the open field farming due to heavy rainfall, wind and natural adverse calamities especially in tropical regions (Von Zabeltitz, 1999). Greenhouse cultivation is a steadily growing sector all over the world (Souza et al., 2002). The utilization of greenhouses, mainly for cultivation of vegetables and ornamental crops is undergoing transformation for modernization that gives an opportunity to improve yield and quality. Greenhouses may range from low cost such as plastic greenhouses to more sophisticated hitchgreenhouses with controlled environment. Greenhouse technology in modern agriculture has many advantages especially of reducing the climatic hazards.

In the present scenario of growing population, it has compelled the farmers to produce more food on less land. In an accessible rooftop, enough space is generally available for localized small-scale urban agriculture. Thus greenhouse or polyhouse technology of advanced agriculture is a good addition to rooftop agriculture. Global warming is also posing further challenge, as it increases the evapotranspiration and thus increasing the water requirement of crops. Usually, evapotranspiration inside a greenhouse is around 60 to $80 \%$ higher than outside and varies with crop type and crop growth stages (Mpusia, 2006). It is known that water is a major issue almost in all parts of the world especially for countries which have insufficient water source. With the expansion of greenhouse cultivation, the need of proper irrigation management becomes more important. Accurate estimations on crop water requirement are needed to avoid the excess or deficit water application, with consequent impacts on nutrient availability for plants, soil salinity and groundwater contamination (Blanco and Folegatti, 2004). A correct determination of actual crop evapotranspiration (ETc) for irrigation scheduling is one of the main factors in achieving high yields and high water productivity.

Hot pepper commonly known as chilli, is the world's third most important vegetable after potatoes and tomatoes in terms of quantity of production. World production of both dry and green chilli is 28.4 million tons from 3.3 million ha area, with an annual growth rate of $0.5 \%$ (FAO, 2007). India is not only the largest producer but also the largest consumer of chilli in the world. India contributes about $36 \%$ to the total world production of chilli and are grown in almost all the states of the country. Andhra Pradesh is the largest producer of Chilli in India and Orissa has $11 \%$ of total Chilli growing area. Besides other crops, chilli is a demand crop more particularly in urban areas and people like to grow it in rooftop gardens. But due to lack of sufficient data on rooftop evapotranspiration, proper irrigation scheduling of the crop is not possible under rooftop cultivation. Thus, combining the greenhouse technology with rooftop cultivation, the actual evapotranspiration of green chilli was determined and its variation was studied under deficit irrigation practices both inside and outside environmental conditions of a rooftop greenhouse.

\section{Materials and Methods}

\section{Experimental site}

The experiment was conducted on the rooftop of College of Agricultural Engineering and Technology, Orissa University of Agriculture and Technology, Bhubaneswar, Odisha, India during the period December 2014 to March 2015. The site is located at $20^{\circ} 15^{\prime \prime} \mathrm{N}$ latitude and $85^{\circ} 52^{\prime \prime} \mathrm{E}$ longitude and an elevation of 25.9 metres above mean sea level. It is located at about $64 \mathrm{~km}$ away from of the west of the 
Bay of Bengal. Elevation difference from the ground surface to the roof top of the college building is 11.3 metres. The mean annual rainfall is about $1451 \mathrm{~mm}$ out of which $80 \%$ downpours during four monsoon months of June to September.

The mean maximum temperature during the hottest month of May and June varies from $38^{\circ} \mathrm{C}$ to $40^{\circ} \mathrm{C}$, and the mean minimum temperature during the colder months of December and January varies from $11^{\circ} \mathrm{C}$ to $14^{\circ} \mathrm{C}$. The atmosphere remains quite humid throughout the year with an average relative humidity of 84 per cent. The average wind speed above $2 \mathrm{~m}$ from ground level is $6.5 \mathrm{~ms}^{-1}$.

\section{Soil}

Soil samples were collected from the field and its textural analysis was done by Bouyoucos Hydrometer method. The chemical properties viz. $\mathrm{pH}$, organic carbon, available nitrogen, available phosphorous, available potassium and physical properties viz. soil texture, bulk density, field capacity, permanent wilting point of the soil were analysed and determined as shown in Table 1.

\section{Treatment details}

Four manageable allowable depletion (MAD) levels of 10, 20,30, 40\% and one control (without any moisture stress) were selected as treatments for the pot experiment both inside and outside the greenhouse.

Each treatment was replicated three times both at inside and outside the rooftop poly house. The treatment details are as follows;

$\mathrm{T}_{1}: 10 \%$ MAD level

$\mathrm{T}_{2}: 20 \%$ MAD level

$\mathrm{T}_{3}: 30 \%$ MAD level

$\mathrm{T}_{4}: 40 \%$ MAD level

T5: Control (farmer's practice)

\section{Greenhouse specification}

The length, width and height of the green house were kept $4 \mathrm{~m}, 3 \mathrm{~m}$ and $1.5 \mathrm{~m}$ respectively. G.I pipes were used for the stand and arch of the green house and UV film (200 micron) was used as cladding material.

\section{Experimental setup}

Thirty numbers of burnt clay pots of same size were used in the experiment. Fifteen pots were kept inside the green house and remaining 15 pots were kept outside the greenhouse to accommodate five treatments with 3 replications. The diameter of each pot was $27 \mathrm{~cm}$ and the height was $30 \mathrm{~cm}$. Each pot contained soil of $68671.8 \mathrm{~cm}^{3}$. One plant was planted in each plot. Chilli variety Utkal Ava (Capsicum annum L.) was selected for the study.

\section{Estimation of actual crop evapotranspiration}

Root zone water balance model as shown in Eq.1was used for determining actual crop evapotranspiration on daily basis.

$S M C_{i}=S M C_{i-1}+P_{i}+I_{i}-A E T_{i}-D P_{i}-R O_{i}$

Where,

$S M C_{i}=$ soil moisture content of $\mathrm{i}^{\text {th }}$ day, $\mathrm{mm}$, $S M C_{i-1}=$ soil moisture content of $\mathrm{i}-1^{\text {th }}$ day, $\mathrm{mm}, P_{i}=$ rainfall, $I_{i}=$ depth of irrigation of $\mathrm{i}^{\text {th }}$ day, mm, $A E T_{i}=$ actual evapotranspiration of $\mathrm{i}^{\text {th }}$ day, mm, $D P_{i}=$ deep percolation of $\mathrm{i}^{\text {th }}$ day, $\mathrm{mm}, R O_{i}=$ runoff on $\mathrm{i}^{\text {th }}$ day, $\mathrm{mm}$.

Other components of the water balance model except AET were measured for each pot. The soil moisture content was determined using digital soil moisture meter. Depercolation water was collected at the bottom of the pot after each irrigation and rainfall. Rainfall was 
effect was neglected for the experiments inside the greenhouse. Irrigation water was applied to each pot, when the soil moisture content reached the respective MAD levels. In control treatment (farmer's practice), irrigation was applied in 7 days interval.

\section{Results and Discussion}

\section{Crop Evapotranspiration}

Crop evapotranspiration was determined using the soil water balance model on daily basis considering the pot as a non-weighing type lysimeter and the actual crop evapotranspiration for different treatments inside and outside the greenhouse are shown in Table 2 and 3, respectively.

It is observed from the Table 2 that crop evapotranspiration inside the greenhouse for different stages of growth for different treatment varied from 22.76 to $200.67 \mathrm{~mm}$ for treatment $\mathrm{T}_{1}, \quad 19.99$ to $178.28 \mathrm{~mm}$ for treatment $\mathrm{T}_{2}, \quad 17.57$ to $150.71 \mathrm{~mm}$ for treatment $\mathrm{T}_{3}, 13.60$ to $123.61 \mathrm{~mm}$ for treatment $\mathrm{T}_{4}$ and 18.5 to $133.02 \mathrm{~mm}$ for treatment $T_{5}$ (control) and the total average crop evapotranspiration throughout the growing period for different treatments i.e. $\mathrm{T}_{1}$, $\mathrm{T}_{2}, \mathrm{~T}_{3}, \mathrm{~T}_{4}$ and $\mathrm{T}_{5}$ was found to be $312.89 \mathrm{~mm}$, $273.28 \mathrm{~mm}, 237.92 \mathrm{~mm}, 195.39 \mathrm{~mm}$ and $216.9 \mathrm{~mm}$, respectively.

The crop evapotranspiration was found maximum for treatment $\mathrm{T}_{1}$ followed by treatments $T_{2}, T_{3}, T_{5}$ and the treatment $T_{4}$ recorded the minimum crop evapotranspiration. Crop evapotranspiration for treatment $\mathrm{T}_{1}$ in which the $10 \%$ MAD level was maintained, was highest because more water was available for evapotranspiration process which resulted in the high water uptake rate from the soil. In rest of treatments moisture stress resulted in the less evapotranspiration. Table 3 reveals that crop evapotranspiration outside the greenhouse for different growth stages varied from 34.07 to $220.3 \mathrm{~mm}$ for treatment $\mathrm{T}_{1}, 23.85$ to 202.78 $\mathrm{mm}$ for treatment $\mathrm{T}_{2}, 18.23$ to $180.0 \mathrm{~mm}$ for treatment $\mathrm{T}_{3}, 13.20$ to $172.3 \mathrm{~mm}$ for treatment $\mathrm{T}_{4}$ and 16.5 to $175.2 \mathrm{~mm}$ for treatment $\mathrm{T}_{5}$ and the total average crop evapotranspiration throughout the growing period for different treatments i.e. $\mathrm{T}_{1}, \mathrm{~T}_{2}, \mathrm{~T}_{3}, \mathrm{~T}_{4}$ and $\mathrm{T}_{5}$ was found to be $337.45,304.15,270.7,248.87$ and $257.93 \mathrm{~mm}$, respectively. The crop evapotranspiration was maximum for $T_{1}$ followed by treatments $T_{2}, T_{3}, T_{5}$ and the treatment $\mathrm{T}_{4}$ recorded the minimum crop evapotranspiration. Crop evapotranspiration for treatment $\mathrm{T}_{1}$ was highest because more water was available in soil which resulted in the highest evapotranspiration.

\section{Variation of crop evapotranspiration in inside and outside of the greenhouse}

The variation of crop evapotranspiration of chilli both inside and outside the greenhouse for different treatments have been presented in the Figures 1 to 5.

The Figures 1 to 5 depict that the actual crop evapotranspiration for green chilli inside the green house was less as compared to outside greenhouse conditions for all stages of growth as well as under all MAD levels of irrigation. For initial stage, the crop evapotranspiration outside the greenhouse was found to be $49.69 \%, 19.30 \%, 3.75 \%, 19.11 \%$ and $12.2 \%$ more as compared to inside greenhouse condition under 10\%, 20\%, 30\%, 40\% MAD levels of irrigation and control treatment, respectively. Similarly, increase of 2.14 and $3.10 \%, 2.97$ and $13.51 \%, 1.19$ and $19.4 \%$, 8.36 and $39.72 \%, 1.19 \%$ and $31.7 \%$ more crop evapotranspiration in development and midseason stages were observed outside the greenhouse than inside conditions under $10 \%$, $20 \%, 30 \%, 40 \%$ MAD levels of irrigation and control treatment, respectively. 
Fig.1 Crop evapotranspiration inside and outside the green house at 10\% MAD level

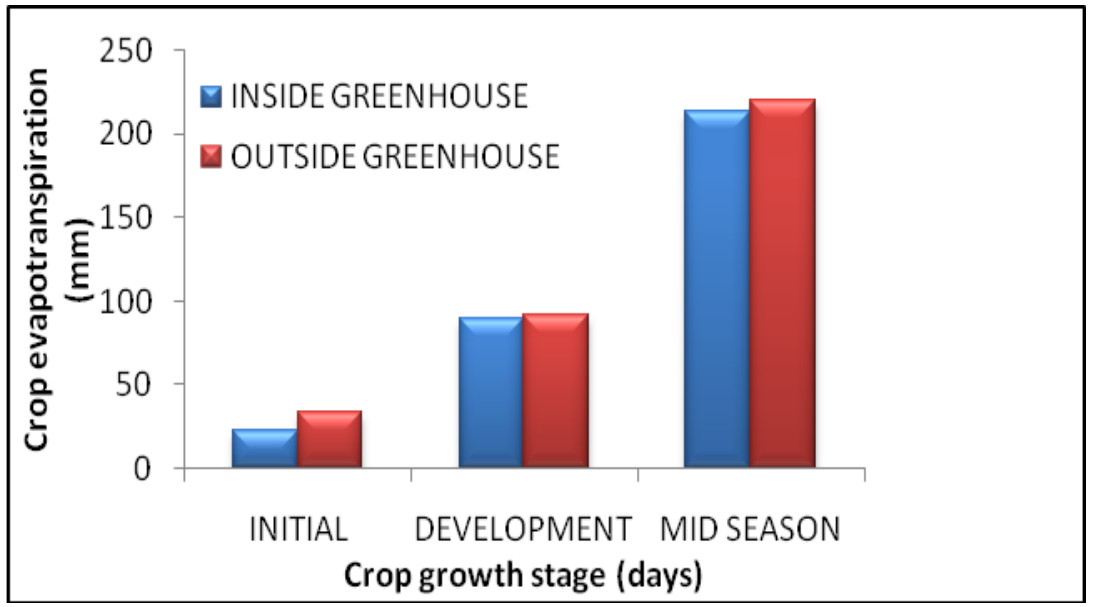

Fig.2 Crop evapotranspiration inside and outside the green house at 20\% MAD level

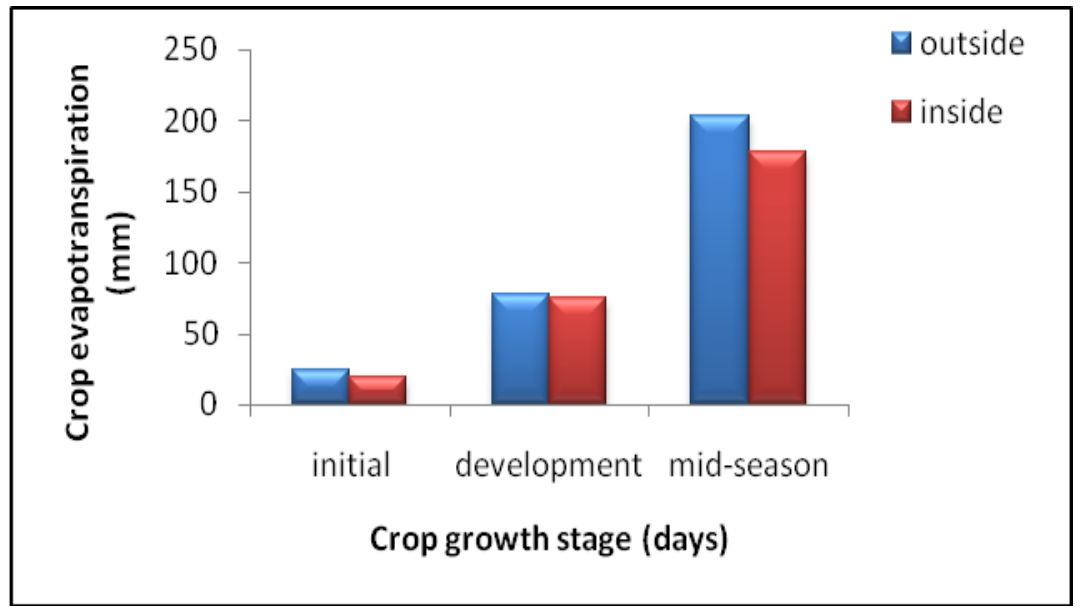

Fig.3 Crop evapotranspiration inside and outside the green house at 30\% MAD level

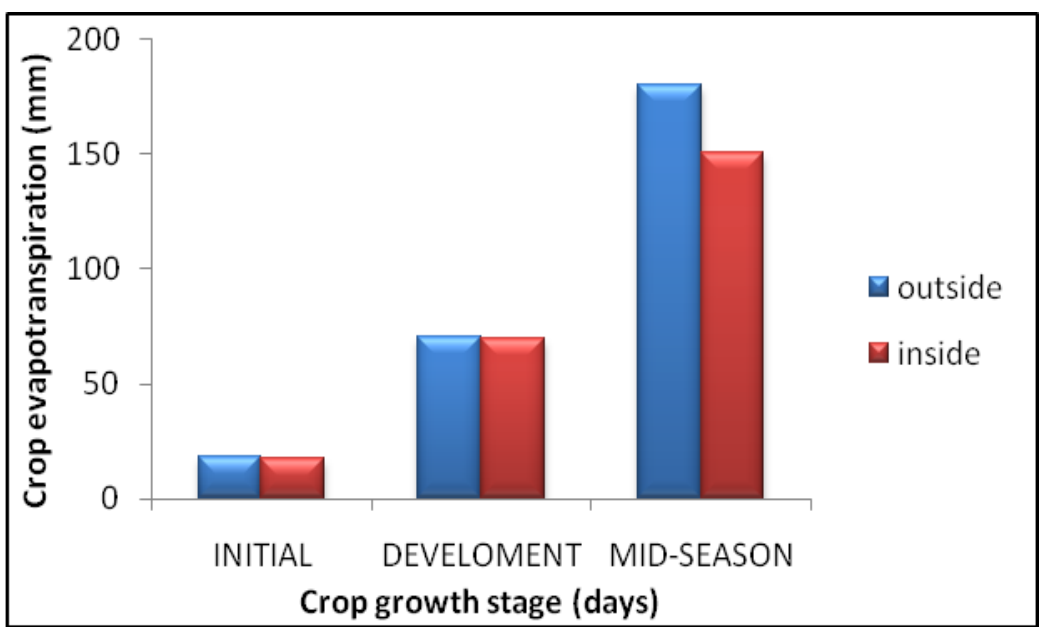


Fig.4 Crop evapotranspiration inside and outside the green house at 40\% MAD level

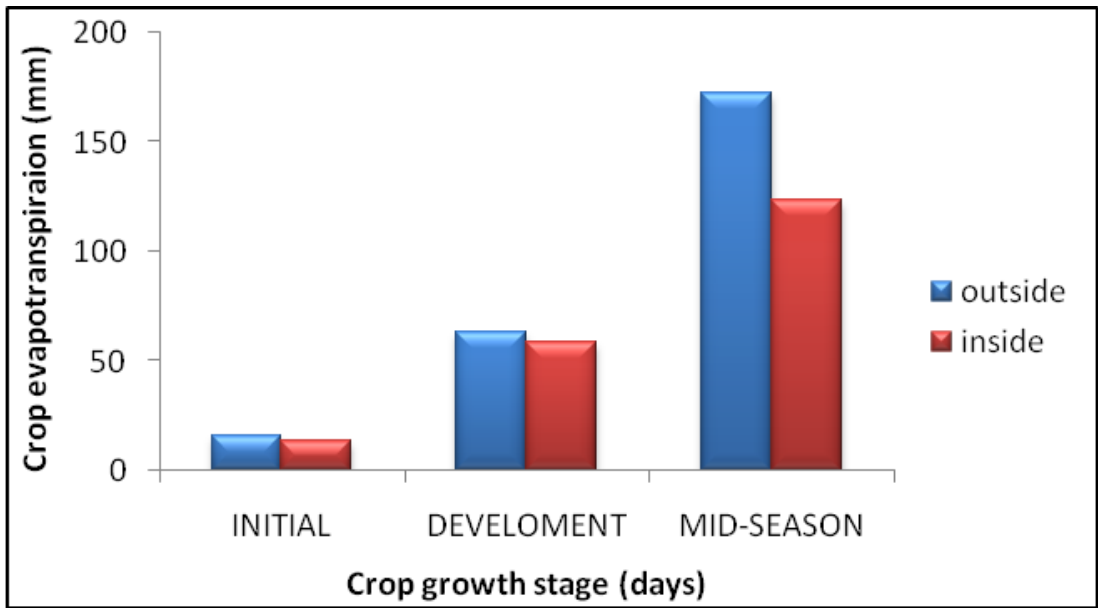

Fig.5 Variation of crop evapotranspiration inside and outside the Greenhouse under control treatment

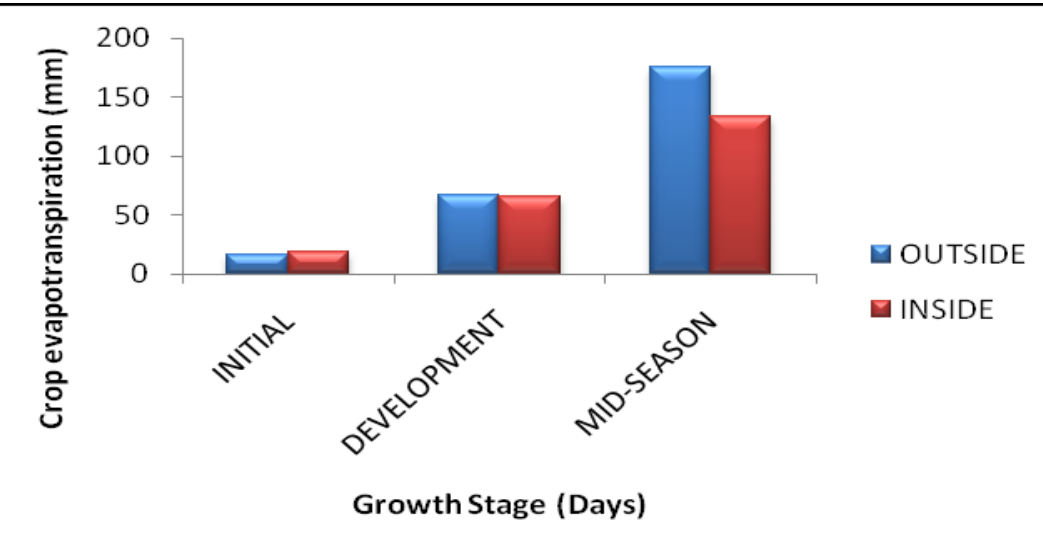

Fig.6 Comparison of yield inside and outside the greenhouse

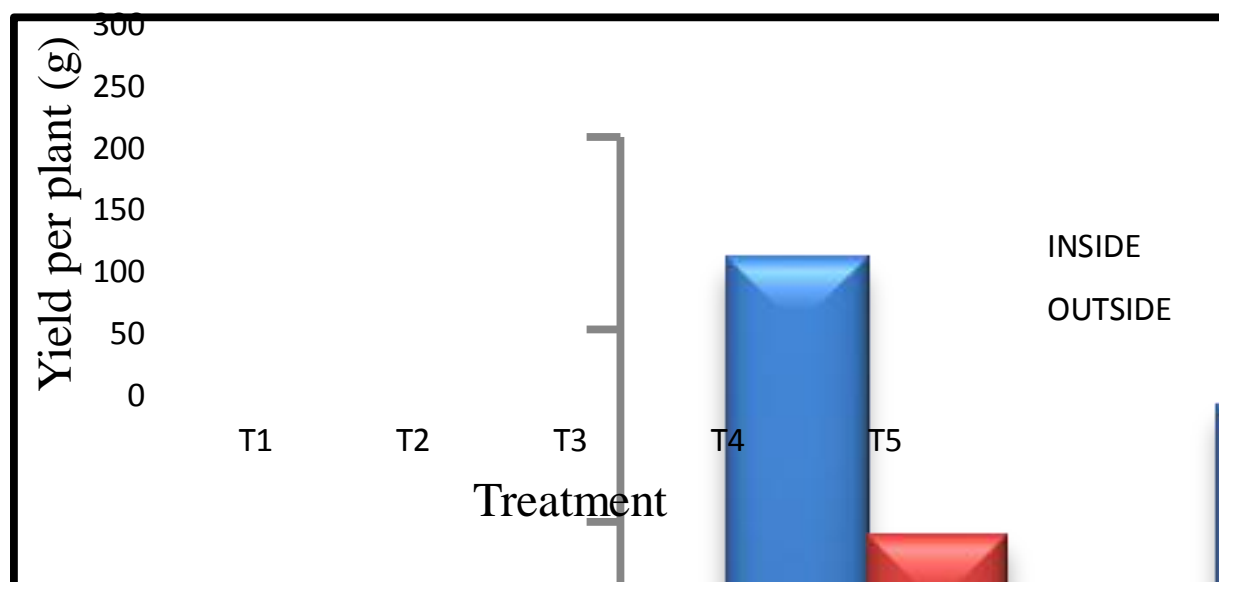


Table.1 Soil physical and chemical properties

\begin{tabular}{|l|c|}
\hline Soil Parameters & Value \\
\hline pH & 4.66 \\
\hline Organic carbon (\%) & 0.48 \\
\hline Available Nitrogen $\left(\mathrm{kgha}^{-1}\right)$ & 180.5 \\
\hline Available Phosphorus $\left(\mathrm{kg} \mathrm{ha}^{-1}\right)$ & 47.8 \\
\hline Available Potassium(kg ha-1) & 41.66 \\
\hline Soil Texture (Sand: 69.5\%, Silt: 20.0\%, Clay: 10.5\%) & Sandy loam \\
\hline Bulk Density (g/cc) & 1.50 \\
\hline Field Capacity (\% v/v) & 18.9 \\
\hline Permanent Wilting Point (\% v/v) & 9.03 \\
\hline
\end{tabular}

Table.2 Stage wise actual crop evapotranspiration measured inside the greenhouse

\begin{tabular}{|l|c|c|c|c|c|c|}
\hline Growth stage & $\begin{array}{c}\text { Growth stage } \\
\text { length (days) }\end{array}$ & \multicolumn{5}{|c|}{ ETc (mm) } \\
\hline Initial & 15 & $\mathbf{T}_{\mathbf{1}}$ & $\mathbf{T}_{\mathbf{2}}$ & $\mathbf{T}_{\mathbf{3}}$ & $\mathbf{T}_{\mathbf{4}}$ & $\mathbf{T}_{\mathbf{5}}$ \\
\hline Development & 30 & 89.76 & 19.99 & 17.57 & 13.60 & 18.50 \\
\hline Mid-Season & 50 & 200.67 & 75.28 & 69.64 & 58.48 & 65.04 \\
\hline Total & 95 & 312.89 & 273.28 & 237.92 & 195.39 & 216.90 \\
\hline
\end{tabular}

Table.3 Stage wise actual crop evapotranspiration measured outside the greenhouse

\begin{tabular}{|c|c|c|c|c|c|c|c|}
\hline Growth stage & $\begin{array}{c}\text { Growth stage } \\
\text { length (days) }\end{array}$ & \multicolumn{5}{|c|}{$\mathbf{E T}_{\mathbf{c}}(\mathbf{m} \mathbf{m})$} \\
\hline Initial & 15 & 34.07 & 23.85 & 18.23 & 13.20 & 16.50 \\
\hline Development & 30 & 83.38 & 77.52 & 70.47 & 63.37 & 66.23 \\
\hline Mid-Season & 50 & 220.30 & 202.78 & 180.00 & 172.30 & 175.20 \\
\hline Total & 95 & 337.45 & 304.15 & 270.70 & 248.87 & 257.93 \\
\hline
\end{tabular}

From the experiment it is observed that evapotranspiration inside the greenhouse is lower than outside for cases. It may be due to the reason that the evaporation component was dominant than the transpiration in outside condition because of climatic parameters like wind velocity, solar radiation, low RH which resulted in the increased evapotranspiration outside the greenhouse, although inside temperature of greenhouse is more than that of outside temperature.
Comparison of yield of chilli inside and outside the greenhouse

Average yield of green chilli per plant inside and outside the greenhouse has been shown in Figure 6.

The chilli yield inside the green house for treatments $\mathrm{T}_{1}, \mathrm{~T}_{2}, \mathrm{~T}_{3}, \mathrm{~T}_{4}$ and $\mathrm{T}_{5}$ were observed to be 268.50, 230.36, 198.60, 170.00 and $188.3 \mathrm{~g} /$ plant, respectively. Maximum 
yield of $268.5 \mathrm{~g} /$ plant was recorded in treatment $T_{1}$ followed by treatment $T_{2}, T_{3}, T_{5}$ and the treatment $\mathrm{T}_{4}$ showed the minimum yield of $170 \mathrm{~g} /$ plant. Similarly, highest yield of $196.68 \mathrm{~g} /$ plant was observed in the treatment $\mathrm{T}_{1}$ for outside greenhouse condition. The yield for treatment $\mathrm{T}_{2}, \mathrm{~T}_{3}, \mathrm{~T}_{5}$ was 175.15 , $155.80,148.75 \mathrm{~g} / \mathrm{plant}$, respectively with a lowest yield of $136.2 \mathrm{~g} /$ plant in treatment $\mathrm{T}_{4}$.

The experiment conducted on growing green chilli in rooftop greenhouse concludes that actual crop evapotranspiration of chilli inside the greenhouse is less than outside greenhouse conditions for all the treatments. The treatment with $10 \%$ MAD level showed the best performance amongst all other treatments followed by the treatments with 20 and 30\% MAD levels and also farmer's practice. The total crop evapotranspiration was $312.89 \mathrm{~mm}$ and $337.45 \mathrm{~mm}$ in inside and outside the greenhouse, respectively under $10 \%$ MAD level. The crop evapotranspiration outside the greenhouse was 49.69, 2.14 and $3.10 \%$ more during initial, crop development and mid-season stages, respectively compared to inside greenhouse condition under $10 \%$ MAD level of irrigation. Higher yields of chilli was also obtained from all the inside greenhouse treatments compared to outside condition. The maximum yield of 268.5 $\mathrm{g} /$ plant was obtained from treatment with $10 \%$ MAD level and the minimum of 170 $\mathrm{g} /$ plant was obtained from treatment with $40 \%$ MAD level. The treatment with $10 \%$
MAD level inside the greenhouse, which performed best amongst all, gave $36.51 \%$ more yield and $18.31 \%$ less evapotranspiration than the outside condition and also the yield was $32.22 \%$ higher than the farmers practice.

\section{References}

Blanco, F. F. and Folegatti, M. V., (2004). Evaluation of evaporation-measuring equipments for estimating evapotranspiration within a greenhouse. Revista Brasileira de Engenharia Agricola e Ambiental, 8: 184-188.

FAO, (2007). Production yearbook. Food and Agriculture Organization of the United Nations, Rome, Italy.

Mpusia, P.T.O., (2006). Comparison of water consumption between greenhouse and outdoor cultivation. Master's Thesis. International Institute for GeoInformation Science and Earth Observation, Enschede, The Netherlands.

Souza, C. M. P., Klar, A. E. and Duenhas, L. H., (2002). Evaluation of Meteorological Elements and Lettuce (Lactuca sativa L) Yield Related to Geographic Orientation of Polyethylene Greenhouses. Irriga, Botucatu., 7(3).

Von, Z., (1999). Greenhouse Structures, Ecosystems of the World's 20 Greenhouses. Elsevier, Amsterdam.

\section{How to cite this article:}

Chopda, A., A.P. Sahu, D.M. Das, B. Panigrahi and Senapati, S.C. 2018. Variation in Actual Evapotranspiration of Green Chilli Inside and Outside the Rooftop Greenhouse under Deficit Irrigation. Int.J.Curr.Microbiol.App.Sci. 7(08): 4152-4159.

doi: https://doi.org/10.20546/ijcmas.2018.708.434 